DOI: $10.20472 / S S .2020 .9 .2 .001$

\title{
CORONA - WHO WAS THE PERPETRATOR?
}

\section{BIRGER ANTHOLZ}

\begin{abstract}
:
Corona will infect tens of millions of people worldwide. Of these, more than a million will die by summer 2020, i.e. become victims of bodily injury resulting in death, i.e. a criminal offence. Up to now, the smallest links in the chain of infection have been punished, e.g. for violation of the distance rule. Would it not therefore be appropriate to ask about the real culprit of Covid-19? In early June 2020, the government of Australia and citizens in northern Italy (Bergamo) are demanding clarifications: who is responsible for the Corona pandemic?

The most important explanations of the origin of the corona virus are presented and discussed. Have residents of the Shitou bat cave carried the virus to Wuhan? Did one of the two well-known Wuhan bat hunters bring it to the Wuhan Seafood Market? Is the zoonosis theory true, according to which a bat at the seafood market infected a pangolin that was then eaten by a human being? Was the Sars-CoV-2 virus developed in a biolab and then escaped through a lab accident? The plausibility of these explanatory theories is discussed.
\end{abstract}

\section{Keywords:}

Covid-19 origin, Corona origin, Sars-CoV-2, conspiracy theory, Shanghai line

JEL Classification: $110,119,138$

\section{Authors:}

BIRGER ANTHOLZ, University of Hamburg, Germany, Email: birger.antholz@public.uni-hamburg.de

\section{Citation:}

BIRGER ANTHOLZ (2020). Corona - who was the Perpetrator?. International Journal of Social Sciences, Vol. IX(2), pp. 1-20., 10.20472/SS.2020.9.2.001 


\section{Introduction}

We accuse (noi denunceremo) chanted Italian citizens in Bergamo during a demonstration on June 9, 2020 (Rüb 2020) who wanted to know who is responsible for the corona deaths (Monitor 2020). Many international groups like the government in Australia demand clarification (Wurzel 2020). Thus, the question of who caused the corona pandemic has changed from a criminological to a sociological question. Who is patient zero, from whom the wave of infection originated?

The four possible origins of the corona virus - resident, virus hunter, zoonoses and biolab hypothesis - are explained in detail one after the other.

\section{Bat cave residents carry the virus to Wuhan}

The Shitou cave has long been known for bats that contain Sars and other viruses. In the immediate vicinity there is the Yanzi cave and a number of smaller villages. Shitou cave is located $1360 \mathrm{~km}(845 \mathrm{mi})$ southwest of Wuhan $(63 \mathrm{~km}(39 \mathrm{~m})$ as the crow flies southwest of Kunming, the capital of Yunnan Province). In this cave a bat Sars virus was discovered, which is $96.2 \%$ identical to the Sars-CoV-2 virus (Zhou et al. 2020). In this cave it was observed how a recombination of a Sars virus occurs when two Sars viruses infect a bat (Wang et al. 2018). The assumption about the origin of Sars-2 (used synonymously for Sars-CoV-2 in the following) is that in 2019, when a bat was infected several times in the Shitou cave, a mutation of the previous Sars-viruses occurred, so that Sars-CoV-2 was formed by chance. To do this, only $3.8 \%$ of an already existing Sars virus would have had to be changed.

Five years ago, Chinese scientists examined the residents around the Shitou and Yanzi caves. In 2015, they applied antibody tests for Sars virus to 218 residents. The tests were positive in six residents, almost 3\% (Wang et al. 2018). These 3\% were therefore carriers of Sars bat viruses. These residents had observed bats in the immediate vicinity of their homes. Therefore, these residents probably contracted the virus directly from the bats. None of the residents could recall an infection, so that the infection did occur but was asymptomatic.

If in 2019 the new Sars-2 virus was created in the Shitou cave by mutation, it could have been transmitted again, for example, to $3 \%$ of the residents in the immediate vicinity of the cave. Maybe six residents were infected again. Among these six residents, patient zero would then have to be found. In 2015 one of the six residents had gone to Shenzhen. This city is $1400 \mathrm{~km}$ (870 m) away (Wang et al 2018). Perhaps in 2019, among the six people who may again be infected with Sars-2, one of the residents went to Wuhan, $1360 \mathrm{~km}$ away? This Patient Zero, who was infected by a mutated bat near the Shitou cave, may have been at the Wuhan fish market for shopping and carried the virus there. Or maybe he visited relatives in Wuhan who were fishmongers?

Another argument for this origin theory emerged in May 2020. By analysing 160 Sars-CoV-2 viruses in a database, the Forster brothers were able to demonstrate that there are now 3 variants of the Sars-2 virus (Krüger 2020). The original variant is type $A$. This is the initial variant because it is most similar to the bat viruses of the Shitou cave. However, this type $A$ does not dominate in Wuhan. There you can find type $B$, which was created by a mutation of type A. Type A first broke out in Yunnan province (Kruger 2020). Yunnan is the province where the Shitou cave is located. 


\section{Virus hunters from Wuhan biolabs}

The Shitou cave was described two years ago as a fire hazard for a new Sars outbreak, because many bat SarsrCoV viruses existed there, which often infect the same individual (bat) (Wang et al. 2018). The famous Chinese bat hunter, the so called 'Batwoman' Shi Zhengli warned of a skipping of bat Sars-related (Sarsr) viruses to humans (Cui et al. 2019). The Chinese horseshoe bat in particular poses a high risk (Ge et al. 2013).

She continuously collected viruses, also from the Shitou cave. There are 1500 bat viruses in her Institute of Virology. It is not unlikely that one of the 1500 viruses was the Sars-2 virus. At first, she herself was worried about the Sars-Cov-2 viruses: "Could they have come from our lab?" (Qiu 2020)

It was found out that the Institute of Virology published a job advertisement on November 18, 2019 , in which a virologist for novel viruses was sought. This leads to the suspicion that the Institute of Virology already knew about a novel corona disease in November 2019. This job advertisement was renewed on 24 December 2019. In the advertisement text of November 18,2019 , there are indications of a symptom-free course of the corona disease which was only officially discovered at the end of December 2019: "Sars-associated corona virus for a long time without causing disease" (Wuhan Institute of Virology). Shi Zhengli officially stated that she had heard of the new corona virus on December 30, 2019 (Quiu 2020). However, her job advertisements indicate that she already knew about the virus and its characteristics, lack of symptoms at the beginning and, in many infected persons, during the course of the infection. Her statement that she only learned about the corona flu on December 30, 2019 (Quiu 2020) must be doubted.

The doubts about the 30th December 2019 she stated are supported by the fact that the Institute of Virology had already decoded the genome of Sars-2 in suspicious record time on 2nd January 2020 (announced with delay on 09.01.2020; Anonymous group of researchers). Was she possible to present the complete gene sequence in three days so quickly because parts of it had been constructed by the institute itself?

Shi Zhengli is responsible for novel infectious diseases in Wuhan. If, since at least November and increasingly from mid-December 2019, Sars-1-like cases have occurred as a new virus disease in Wuhan, she would be the first contact person. It would be hard to explain why people would have hesitated half a month until December 30, 2019 to let her know. Her claim to have learned about Corona on December $30^{\text {th }}, 2019$ - mostly reproduced in a generously embellished story (Quiu 2020) - seems unbelievable. How credible is her claim that no Sars-2 virus was found in her biolab? Why had she disappeared from the public eye for three months in order to start a new diversionary maneuver in front of the press right after her appearance? (Burke 2020)

Shi Zhengli was called on December 30, 2019 in Shanghai (Qiu 2020). Only two weeks later the corona virus appeared there in the form of the Shanghai line (type C). In 2013 Shi Zhengli finds the Sars-Cov-2 predecessor in the Shitou cave in Yunnan and in 2019 Covid-19 breaks out with the original corona type A in Yunnan. In November 2019 Covid-19 erupted with the corona type $B$ in Wuhan near her Institute of Virology. The successive outbreaks of corona type A (Yunnan), corona type B (Wuhan, $1360 \mathrm{~km} / 845 \mathrm{~m}$ away) and corona type C (Shanghai, another $700 \mathrm{~km} / 435 \mathrm{~m}$ away) can hardly have been caused by intermediate host animals such as bats or pangolin because of the distances. But they do have one thing in common: Shi Zhengli was there before. 
In Wuhan there are several biolabs. The above mentioned Institute of Virology is $12 \mathrm{~km}(7,5$ m) away from the Wuhan seafood market. Only 280 meters (918 feets) from the seafood market is the Center for Disease Control and Prevention located. In the Centre for Disease Control and Prevention there are 600 bats, many of them with Sars-viruses. The bat collector there is Tian Junhua. Tian Junhua has been responsible for hunting and collecting bats and bat viruses since 2012. Like his colleague Shi Zhengli from the Institute of Virology, he is usually right at the front line in the bat caves. Catching a bat, for example to take saliva samples from it, is a dangerous and dirty job that requires a lot of experience. That is why it is hardly delegated and Tian Junhua personally carries out this bat hunt. He was only sometimes accompanied by his wife. Tian Junhua was very active: "155 bats, including Rhinolophus affinis, were captured in Hubei province, and another 450 bats were captured in Zhejiang province" (Xiao \& Xiao 2020). This means that Tian Junhua has visited caves other than Shi Zhengli. In the Shitou cave investigated by Shi Zhengli, there were officially viruses that were $96.2 \%$ identical to Sars-2 (Zhou et al. 2020), but no corona viruses that were $100 \%$ identical to Sars-2. However, these could have been in the caves investigated by Tian Junhua in the other Chinese provinces Hubei or Zhejiang. In caves in Zhoushan in eastern China, bat viruses were found that were $88 \%$ identical to Sars-2 (Lu et al. 2020).

In a film from December 2019, in which his virus hunt is presented, it says at the end that before China's entry into the search for viruses, only 2284 virus types had been found worldwide. In the last 12 years, almost 2000 new virus types have been discovered by Chinese researchers (182 days, film minute 6:53). So there was a competition who discovered more new viruses. All these new viruses were brought to the biolabs in Wuhan, partly with the corresponding bats.

There have been repeated warnings about the Shitou cave, where Sars viruses have been found in large numbers between 2011 and 2015. Already the Sars-1 virus came from here (Hu et al. 2017). The Sars-2 virus probably also has its bat-virus origin here, because the virus BATCoV RaTG13, which was allegedly found here in 2013 , is $96.2 \%$ identical to Sars-CoV-2 (Zhou et al. 2020). If the Chinese bat hunters had left the bats in the Shitou cave alone, no virus would have reached Wuhan. It was not climate change or human intervention in nature (e.g. clearing forests), but the targeted intrusion of the virus researchers into the Shitou cave with the aim of extracting the virus, that carried the Sars-2 virus into mankind. The Sars-2 pandemic is not caused by technology (climate change) or society (land use), but can be traced back to individuals (virus researchers). To contain African swine fever, China culls 1.3 million pigs (Norhoff 2019). China had carefully mapped the bat caves nationwide. It was known that only in the two Yunnan caves did Sars-viruses naturally remix. If the virus was not artificially created in a bio laboratory, it was created in the Shitou cave. China could have prevented the Corona pandemic by killing all bats in Shitou Cave and the adjacent Yanzi Cave prophylactically.

Tian Junhua reported that he may have been infected repeatedly (Xiao \& Xiao 2020). He went into quarantine twice. It could well be that among the many new bats he has caught in recent years there was a mutated bat that had the new Sars- 2 virus. This could have infected him. Because he did not show any symptoms of disease in the past, even after contact with the urine or faeces of bats, it is possible that he could have gotten through Covid-19 without symptoms. Nevertheless, he could have been a carrier of the Sars-2 virus for some time and spread it in his environment. He lived next to his bio-laboratory, just about 300 metres away from the seafood market. He probably went there with his family to shop in his spare time. In his video there are pictures showing him in scenes that could have been taken in the run-up to an animal market (182 days, film minute 3:53). Tian Junhua could be the first patient zero to 
be infected with Corona. It could also be explained that he spread the Sars-2 virus at the Wuhan seafood market from November 2019.

His Center for Disease Control and Prevention only has biosafety level 2. Therefore the virus could have escaped unnoticed there. The authors Xiao Botao and Xiao Lei (2020) suspect that the corona cause is waste contaminated with Sars-2 viruses, which was improperly disposed of. If a tanuki (= Japanese raccoon dog) had eaten this contaminated waste, it could have been infected and could have infected his conspecifics in a cage at the seafood market 280 metres away. There is also the suspicion that animals were brought from the laboratory to the animal market after the animal experiments in order to sell them there (as animal food) (Mirke 2020).

Suspiciously simultaneous to the outbreak of corona disease, a video of Tian Junhua showing him hunting bats is be released in December 2019. It is astonishing that he suggests a 14-day quarantine. How did he know the long quarantine period of Sars-Cov-2 already in December 2019? The Sars-2 quarantine period of 14 days is longer than for any other comparable viral disease. The WHO announced an infection period of up to 14 days for Corona on February 16, 2020 (WHO 2020). Why did Tian Junhua know about 14 days already in December 2019? Some believe they can see almost live on a video how the Sars-CoV-2 virus spread to him and mankind: "The bat's urine dripped from his head like raindrops" (archive today 2017). That Tian Junhua is highly suspected to be the culprit zero is confirmed by the fact that he has been disappeared since December 2019.

\section{Zoonosis on seafood market}

The seafood market in Wuhan is often mentioned in connection with the emergence of corona. This seafood market, which offers fish and some animals, is the origin of the corona virus. This is the official Chinese and German version of the corona origin. Declarations of origin deviating from this are called conspiracy theories.

According to the official version, the excrement of a bat infected with Sars-2, which was standing in a cage above a pangolin animal, would have fallen into the cage of a pangolin animal standing below. This would have been infected by the bat. When a market visitor bought and ate the pangolin, he would have been infected with Sars-2 from the pangolin. Or an animal market trader would have been infected when handling pangolins.

There is a serious objection to this zoonosis origin theory: there were neither bats nor pangolins at the Wuhan seafood market. Therefore, this transmission path could not have taken place there. The trade with pangolins is prohibited since 2013 (Prowildlife 2016). There would have been 10 years imprisonment as punishment for traders of pangolins at the seafood market. In most cases, traders and sellers can be traced by name via cashless payment transactions. That there were no bats at the market is confirmed by many photos and the scientists Botao Xiao and Lei Xiao. They also say that it is very unlikely that a shy, normally location-bound bat flew $1360 \mathrm{~km}$ from the Shitou cave of Yunnan to the megacity of Wuhan and relieved itself over the seafood market (Xiao \& Xiao 2020).

The official theory of origin about a naturally mutated bat, which Sars-2 passed on to a pangolin animal at the market in Wuhan, which was eaten by customers, can be classified as very unrealistic. Nevertheless, in July 2020, the WHO (July 15, 2020) on the Wuhan Seafood market still states: "The virus could have been introduced into the human population from an animal source in the market." The German government (July 5, 2020) claims on the corona cause "that the virus originates from wild animals. The first patients have apparently been infected at a Huanan seafood market in the Chinese city of Wuhan". 
At the zoonotic transition point in December, the bats in China were hibernating. How would they have gotten to the Huanan Seafood Market in Wuhan? Even in Yunnan, 845 miles away, they did not take any trips into the wild. At that time they could not be caught with nets at cave entrances and therefore could not be reached by animal market traders.

There is one point in their report (Xiao \& Xiao 2020) that has received little attention so far. They write that the virus was present in only 33 of 585 samples from the seafood market. So $5.6 \%$ tested positive for corona (about 95\% negative). In Germany, the positive test quotas were higher in the calendar weeks from March 9, 2020 to April 19, 2020. In the week from March 30, to April 5, 2020, 9.0\% of all Sars-CoV-2 tests in Germany were positive (Robert Koch Institute 2020). This is almost twice as many as at the seafood market in Wuhan. Nevertheless, nobody thought that Germany was the place of origin of the virus.

\section{Biological laboratory \\ 5.11000 nucleotides changed in autumn 2019}

There are isolated hypotheses that the Sars-CoV-2 viruses were artificially produced in a biological laboratory. This could have happened by crossing bats or by double-infecting bats or by mixing two strains of Sars virus in the test tube. It is also possible that part of the RNA frequency was directly exchanged in a biolab.

Actually, one might think that the genome structure of corona RNA would enable the identification of its origin. However, the discussion has been going on for several months now and the quintessence is that it is not possible to decide from the nucleotide frequency of the Sars-2 virus whether it was created artificially or by mutation. The Sars-2 virus is $96.2 \%$ identical to the bat virus BATCoV RaTG13 (Zhou et al. 2020). It is $97 \%$ identical to BAT Sarslike CoV Rs4231 and BAT Sars-like CoV Rs4874 (Zhang et al. 2020). This means that the change to Sars-2 is only $3 \%$ to $3.8 \%$ of the RNA strand. There was a gene jump somewhere in autumn 2019. Of the 30,000 nucleotides of the RNA strand, about 1000 were changed. Since then, the Sars-2 virus has changed very little. It mutates far less than flu viruses. Only once or twice a month a mutation occurs (Kupferschmidt 2020). The Sars-2 viruses are 99\% identical between patients ( $\mathrm{Lu}$ et al. 2020). This current constancy of the previously very mutagenic Sars-2 virus is surprising. If the Sars- 2 virus was caused by a big mutation, it should now actually be particularly mutation-friendly.

The gene jump of $3 \%$ mainly concerned the docking to the human receptor molecule angiotensin-converting enzyme 2 (ACE2). This enabled the virus to enter humans. Is the change of about 1000 nucleotides for better docking to ACE2 now artificially caused? Or were there previously more frequent natural genetic alterations that were only not noticed because they did not allow docking to ACE2 and thus did not become disease-causing in humans? The second change is the ability to react to furin, which makes it easier to attach to the human host cell. Furin cleaves the virus, which gives the spikes more possibilities to attach to a cell. This small gene segment used for furin instrumentation is contained in Sars-CoV-2 in contrast to the very similar BatCoV RaTG13 and Pangolin-CoV viruses (Zhang et al. 2020). It appears as if a virus comparable to Sars-CoV-2 was present in autumn 2019, whose serious disadvantages were a weak ACE2 docking and lack of furin metabolism. In 
September/October 2019, this Sars-2 precursor was improved by a gene jump or an exchange of 1000 nucleotides, resulting in Sars-CoV-2.

Some researchers, such as the Australian Holmes, believe this corresponds to an average of 50 years (and at least 20 years) of evolutionary change (University of Sidney 2020). You can quickly calculate this yourself: Sars-CoV-2 mutates once or twice a month (about 18 times a year). 1000 divided by $18=55$ years. The change from BatCoV RaTG13, found in 2013, to Sars-2 in only six years can hardly have occurred naturally: "The genome of this pathogen and that of Sars-CoV-2 separate about a thousand mutations. Scientists conclude from this that the last common ancestor of the two pathogens circulated about 20 to 70 years ago" (Köppe 2020). Other researchers suspect common ancestors in the 1960s (est 2020).

If both viruses would have taken decades to merge, the question arises why they were overlooked when all 84 corona bat viruses, including Rhinolophus affinis, of the Yunnan bat cave were discussed in detail in 2017 (Hu et al. 2017). Apparently, both Sars-CoV-2 and BATCOV RATG13 were not previously in the cave from which they broke out in 2019.

Although there are actually many arguments in favour of changing the Sars RNA strand using genetic scissors, the vast majority of researchers argue for natural alteration through mutations. The reason for this is that the sudden change that occurs in autumn 2019 would have looked different if it had been made by humans. The change that occurred would look like a false plan that works against all expectations and could therefore only have come about naturally (tberg 2020). Although Sweden is otherwise heavily criticised, it is a Swede, Andersen, of all people, who gives the opinion of most researchers here: "Our analyses clearly show that SARS-CoV-2 is not a laboratory construct or a purposefully manipulated virus" (Andersen et al. 2020).

But is it not conceivable that gene scissors could be used to make massive, automated changes to the RNA structure until the virus was able to penetrate human cells? For the possible RNA alterations that were tried out, it was possible to use the Sars-1 virus, which had the ability to dock to human cells (also via the ACE2 receptor).

The US researchers demonstrated that a modification enables the replication of Sars-viruses in human cultures (Becker 2008). "The first artificially created corona viruses did not reproduce as intended in monkey cell cultures. After a minor modification in the gene of a virus receptor, rapid replication occurred. Outside the laboratory this could mean the beginning of a pandemic" (Ärzteblatt 2008). From joint research in 2011/12, Americans possessed Sars-viruses from the Yunnan Caves (Ge 2013 et al.). Chinese researchers were also able to reconstruct a bat virus in such a way that it could penetrate human cells. Shi Zhengli described in 2008 that she modified a bat-Sars virus by altering the peptide sequences in the spike protein in such a way that it could dock to the human ACE2 receptor (Ren et al. 2020). The German biosafety level 4 laboratory on the Isle of Riems in the Baltic Sea also conducted research with Sars-viruses and attempted to infect large animals with them (Boytchev 2016). In the three bio laboratories of Fort Detrick (USA), Institute of Virology (Wuhan, China) and Isle of Riems (Germany), the technology was available to modify sars bat viruses so that they could infect other human cells.

The bio laboratory thesis states that the virus Sars-2 was artificially created in a bio laboratory. However, it is not assumed that the virus was released intentionally, but rather that it was released accidentally. The bio weapons hypothesis never belonged to the serious conspiracy theories (tberg 2020), because the damage was too great in their own country. There was only the bio laboratory accident theory according to which employees who had accidentally 
contracted the virus would have carried it to the outside world. There are conspiracy theories about three countries.

\subsection{USA Biolab Conspiracy Theory}

The spokesman for the Chinese Foreign Ministry accused the United States of having brought the Sars-2 virus from America to the military world games in October 2019 to Wuhan. "In social media the cyclist and army reservist Maatje Benassi was denounced as 'patient zero'" (Lützow 2020). These military world games, which took place from October 18 to 27, 2019 with 10,000 participants and 230,000 supervisors (bar/sid 2020), would be an ideal starting point for spreading a new virus worldwide, the conspiracy theory goes on.

The fact that the disease first became known in Wuhan is explained by the 230,000 helpers, most of whom came from Wuhan. The fact that an outbreak was first discovered at the seafood market in Wuhan could also be explained. If someone fell ill or died from this new disease, it was initially interpreted as influenza. It took a group of sick people who all appeared together in a hospital. Only there was the commonality of the disease recognized.

The US conspiracy theory is being made more precise in the USA. In the summer of 2019 there was an incident in the US biological laboratory Fort Detrick in the city of Frederick (70 $\mathrm{km}$ northwest of Washington). According to an article in the New York Times (August 5, 2019), the US health authority had ordered the Centre for Disease Control and Prevention to close the Fort Detrick bio-laboratory because contaminated waste had leaked out: "Deadly Germ Research Is Shut Down at Army Lab Over Safety Concerns. Problems with disposal of dangerous materials led the government to suspend research at the military's leading biodefense center." The biolab, which produced bio weapons until 1969, was closed in August 2019 because germs, presumably viruses, leaked.

What could these leaked viruses have caused? These leaked viruses could be behind a new lung disease that appeared in the USA in the summer of 2019. The number of cases was "sharply increasing in August 2019 and peaking in September" (Centers for Desease Control and Prevention). The graphs showing the number of hospitalised patients and deaths in the USA from August to September 2019 are similar to the initial course of the new lung disease Covid-19. At that time, Covid-19 was not known and the lung disease was given the name Evali (E-cigarette, vaping, associated lung injury). The US government blames the smoking of E-cigarettes (vaping), especially the burning of tetrahydrocannabinol (THC) and vitamin E acetate in it, for this novel lung disease. However, e-cigarettes, like cannabis, have been on the market for some time and cannot explain an outbreak of the disease in August 2019. The course since 2017 shows that there have been hardly any cases of Evali before. After September 2019, hospital admissions decrease sharply, although e-cigarettes do not decrease, so that graphically the typical bell-shaped course of an infection (increase until peak in September, then decrease) can be seen (Krishnasamy 2020).

The conspiracy theory now says that US athletes have been infected with this novel lung disease, which may have been Covid-19, and brought the virus to Wuhan at the US Military World Games in October 2019. Accused of being Patient Zero, Maatje Benassi was employed by the military at Fort George G. Meade Army Base. This is in the city triangle of Frederick, Baltimore and Washington. She may have trained on bicycles with employees of nearby Fort Detrick in Frederick.

What is the truth of this conspiracy theory? There was a new type of lung disease in the USA in August and September 2019. 2807 hospitalized and dead were counted until the onset of corona on February 18, 2020 (Krishnasamy 2020). But there was no confirmation that Evali 
had anything to do with Corona. The decrease of Evali from October 2019 in the USA is only provisionally explained by less use of vitamin E acetates. Could it be that from October 2019 onwards the new lung diseases started not to be counted as Evali, but one did not know yet how to name them alternatively?

The parallels between Evali and Covid-19 are striking. Both show the same milky lung in the computer tomography. In both cases about $2 / 3$ of the men fall ill and the dead are about 30 years older than the survivors. The death rate of $0.26 \%$ is just as high as the death rate of Covid-19, which, according to the evaluation of the University of Stanford, including all worldwide data, is $0.25 \%$ in the median (Heinen 2020). The disease symptoms of Evali and Covid-19 are the same: shortness of breath, cough, fever.

Conspiracists argue that the USA is the only country where all types of the corona virus occur. In the USA there is also the Sars-CoV-2 variant type A, which most closely resembles the bat virus (rme/Ärzteblatt 2020). This suggests that the virus originated in this country. Another source of irritation is the fact that in the USA warnings of a pandemic outbreak in Wuhan were reported to the secret services as early as November 2019 (Margollin \& Meek 2020). How did the US secret services know about this, although the Chinese did not report anything about it until December 31, 2019? Did they have anything to do with the outbreak?

What speaks against the US bio-laboratory conspiracy theory is that patient zero, US sportswoman Maatje Benassi, has no corona antibodies (and neither does her husband, at least according to the official announcement; Arré 2020). This means that she could not have spread the virus in Wuhan in October 2019. Her military unit is located near Frederick, but still $70 \mathrm{~km}$ (43 miles) away. She was selected by US conspiracy theorists only because she had fallen at the end of a $50 \mathrm{~km}(31 \mathrm{~m})$ bike race in Wuhan (allegedly out of Corona weakness, but because of her fall her name was in the media).

Actually, the USA could very easily eliminate all conspiracy theories on this subject. They would only have to test the 280 Wuhan athletes of that time. Furthermore, the USA could have blood samples from August to October 2019 tested for the corona virus in the USA retrospectively. It would be particularly easy to test the blood samples of the novel lung disease Evali retrospectively for Covid-19. If there were PCR or antibody detection for SarsCoV-2 in the USA in August and September 2019, the official theory of the Wuhan seafood market as the corona origin in December 2019 would be cleared out. However, the suspicion against US military athletes as corona causers would increase if the Sars-2 virus would be detectable in the USA as early as August and September 2019. The Americans would no longer be able to claim that the Sars-2 virus had escaped from the Institute of Virology in Wuhan in a biolab accident in October 2019.

The Chinese accusation that the Americans spread the Sars-2 virus in Wuhan in October 2020 is closely related to the reports of athletes at the military world games who allegedly felt corona symptoms in Wuhan in October 2019. One Italian sportsman who happened to have a name similar to that of the Italian patient zero (Mattia), who was also an athlete, became particularly well known in the media: "Matteo Tagliariol, who took part in the fencing competitions in Wuhan, also told the Italian sports newspaper Gazzetta dello Sport about typical corona symptoms. 'When we arrived in Wuhan, almost all of us became ill. But the worst thing was to return home. After a week I got a very high fever. I felt that I wasn't breathing. The illness didn't go away even with antibiotics. It took me three weeks to recover and I suffered from weakness for a long time'" (ka 2020). Other teams also reported flu-like symptoms at the military world games in Wuhan. 
This rumour that the military world games were the first superspreader has been around for months. The reactions of the countries to this are strange. "About 30 of the 350 German delegation were treated with respiratory diseases by military doctors", is interpreted as no sign of Covid-19 (Dreis 2020). Germany could test its nearly 250 military world athletes for antibodies for 5000 Euro $(0.00001 \%$ of the defence budget). But it does nothing. Why? If it is discovered that the virus was already spread in Wuhan in October 2019, the zoonosis development thesis on the seafood market in December 2019 would be dropped for time reasons. Although a French military athlete complained about Covid-19 symptoms, France also did not carry out antibody tests and banned its military athletes from continuing to talk to the press (Ibbetson 2020). The USA did not test their athletes either. Why? Only Sweden announced that two athletes had antibodies (ka 2020). However, Sweden in particular could have acquired the corona antibodies later in Sweden. It is quite strange that after months almost no country has tested its military world athletes for antibodies afterwards. In the meantime, antibody tests of military world game athletes have been so delayed by the countries that positive antibody test results are no longer meaningful due to the increased rate of infected persons in the countries.

In the aftermath, people wondered why the USA, which normally leads in sports competitions, did so badly in Wuhan: "USA was able to claim the 35th place behind Finland, ... Countries such as Bulgaria, Tunisia and Namibia ranked ahead of the dominant military power USA. ...It was also by far the worst performance of a US team at all Military Olympics. Did they really send the best military athletes?" (Hellmeyer 2020) It's impossible to ignore that strange US military athletes were sent to Wuhan. What was their mission?

\subsection{Germany Biolab Conspiracy Theory}

Germany was the first country in Europe to experience an outbreak of corona in January 2020. At the automotive supplier Webasto near Munich, a total of 16 people were infected by a Chinese woman who had given workshops there coming from China (Shanghai). From the Webasto cluster, which is characterized by a special corona type $C$ (Shanghai line), the virus spread throughout the Western world, as shown by family trees of genetic kinship.

However, the conspiracy theory refers to a prehistory that occurred before the official corona start (December 2019 Wuhan Seafood Market). Germany is blamed for the outbreak of the corona epidemic in autumn 2019 in Wuhan, because no one less than German Chancellor Angela Merkel gave a speech in Wuhan on September 7, 2019. This took place only $19 \mathrm{~km}$ away from the seafood market. Shortly before that, in August 2019, Angela Merkel gave a speech at the Baltic Sea, only $22 \mathrm{~km}$ away from the German bio research laboratory on the island of Riems. At that time, she discussed with an audience of 200 people. It is assumed that employees of the German biolab on the Isle of Riems were present. Is it possible that Angela Merkel shook hands with Thomas Mettenleiter, the head of the biolab from the island of Riems, whom she knew personally from the joint opening of the biolab a few years earlier? In this conspiracy theory, the virus would have been carried from the German bio laboratory on the island of Riems via Angela Merkel to Wuhan.

Above all, this conspiracy hypothesis was fuelled by the fact that Angela Merkel opened the branch of a German company on the afternoon of September 7, 2019, whose name was on everyone's lips at the time of the Corona start in Germany: Webasto. Chance went one step further. She also met the Chinese woman who was responsible for the outbreak in Munich four months later. Angela Merkel met patient zero on September 7, 2019, who started the entire European and further corona outbreak on January 19, 2020 (Sauter-Orengo 2020). 
How can this conspiracy rumour be assessed? It would be clear that Angela Merkel is talking to Chinese President Xi Jinpeng and Prime Minister Li Keqiang during their visit to China. However, she would only have spoken to any other Chinese with a probability of 1 in 1.4 billion (Chinese). It can no longer be regarded as coincidental that she of all people meets patient zero. Winning the lottery in Germany has a chance of 1 in 14 million, which is about 100 times more likely than meeting a specific one of 1.4 billion Chinese. It would be as if Angela Merkel had won the USA Powerball lottery five times in a row. This probability is very small and its arrival by chance can be ruled out. If it was not a coincidence that Angela Merkel met patient zero (for Germany and Europe) in September 2019, then there would be a connection, but which one?

What speaks for, what speaks against this conspiracy theory? From the very beginning, Germany denies being at the beginning of any chain of outbreaks, just like the USA and China. Although the phylogenetic family tree (same virus type in the Munich Webasto cluster as in northern Italy) seems to provide quite clear evidence, a Webasto guilt is denied with a trick. Other Chinese who would have flown from Shanghai to Italy would be to blame (Kupferschmidt 2020). The problem with this German excuse is that Italy stopped all air traffic between China and Italy at the end of January 2020, before all other EU states (dpa-AFX 2020). In recent weeks there have been increasing reports that the virus in Wuhan already broke out in September (ka 2020). In September 2019 Angela Merkel was in Wuhan and explanation theories that refer to an outbreak from October 2019 onward are becoming more irrelevant.

\subsection{China Biolab Conspiracy Theory}

The third biolab conspiracy theory revolves around the Wuhan bio-laboratories and was already been explained in chapter 3 Virus Hunters. In addition, it should be mentioned that an outbreak of the Sars-2 viruses originating from the Institute of Virology in Wuhan is supported by the fact that from October 7 to 24, 2019, it could be observed that there were almost no mobile phone movements on the premises of the Institute of Virology (Dilanian et al. 2020). This is interpreted as meaning that the Institute of Virology was temporarily closed in October 2019. This indicates an uncontrolled virus outbreak on October 06, 2019. In particular, the Institute of Virology is accused for the injection of corona viruses into piglets and a laboratory accident that occurs (Weimer 2020).

The name of the Chinese employee who is believed to have been responsible for this can also be found on the Internet (Anonymous group of researchers 2020). Huang Yanling worked directly in the biology laboratory at the Institute of Virology in 2015. In social media it is assumed that she was infected in the laboratory and died (Zhen 2020). Her picture was deleted from the staff institute website in February 2020. The fact that there is more than a rumour behind Huang Yanling shows that the Beijing News tried to get to the bottom of it at the institute. The institute management and Shi Zhengli got entangled in contradictions. In the end, it was said that Huang Yanling had left the institute and was working in other provinces (Anonymous group of researchers 2020). Strangely enough, however, this patient zero has disappeared despite intensive searches in social networks and at Weibo, so that one has to assume that she has passed away and her death is being covered up. Patient zero in the USA Maatje Benassi as well as Shi Zhengli, who is suspected to be the source of the virus, deny in the media/social networks to have anything to do with the outbreak. Huang Yanling remained silent. If she were still alive, she would have justified herself to save her reputation. 
A group of authors, using many specialist publications, proves that Wuhan biolabs researched with Sars transitions to humans. In addition, they cite dozens of articles on bio laboratory accidents, two of them in Wuhan only recently (Anonymous group of researchers 2020). The fact that the Chinese Ministry of Science and Technology issued new biosafety guidelines for bio laboratories on February 17, 2020 is like admitting one's own mistakes. Suspicious and an obstacle to tracing back traces to corona origin was that Chinese officials ordered the destruction of all (Sars-2) virus samples on January 3, 2020 (The Taiger 2020).

How should these biological laboratory conspiracy theories be assessed? If one assumes a bio laboratory accident, then of all three countries - the USA, Germany and China - this most likely speaks for China, because the virus was first noticed in Wuhan. It is strange that not only China, but also the USA, Germany and France participated in Wuhan bio laboratories. The US National Institutes of Health funded the research of the Institute of Virology with 3.7 million dollars (fields 2020). This Institute of Virology, which is specifically concerned with highly dangerous Sars-viruses or corona viruses, was established in 2015 in cooperation with a French research institute. It went into operation in early 2017. France supplied the safety technology, but recently withdrew almost completely from the project because it was not satisfied with Chinese standards. The French were therefore responsible for the protective equipment of the Institute of Virology in Wuhan. If a virus had overcome these protective devices, France would have been partly to blame. But other countries are also involved in the bio laboratories in Wuhan. In 2017 the German-Chinese research laboratory "Wuhan-Essen Joint International Laboratory of Infection and Immunity" was founded in Wuhan (Stiftung Universitätsmedizin Essen 2020). Already two years ago, US experts from the US Embassy in Beijing warned of an outbreak of a corona virus from the laboratory of the Institute of Virology after an inspection in early 2018.

Since 2013, the BATCoV RATG13 virus, which is very similar to Sars-2, was allegedly present in the Institute of Virology without being studied. However, the gene sequence of this virus would be very interesting because it could potentially infect humans and Shi Zhengli would have written papers on this virus in 2013-2019 and not on other, much more boring bat viruses (Nerd has power 2020). In early 2020 she said that it is $96.2 \%$ compatible with SarsCoV-2. Here, too, it is surprising how quickly this high level of correspondence with this virus was found in the Wuhaner database among 2000 viruses. Exposing it is said that BATCoV RATG13 was investigated since 2019 (est 2020). What changes in the investigation have been made by the Institute of Virology in 2019 ?

Shi Zhengli registered this virus BATCoV RATG13 on January 27, 2020 by specifying the sequence order (without actually delivering this virus). The conspiracy theorists go one step further: computer experts have now discovered that the virus has too many deviations in some places and too few in others. If the virus had been altered by natural mutations, the 3.8 percentage points of nucleotide difference to the Sars-2 virus would be evenly distributed across the entire RNA strand. However, in some places there are very few mutations and in other places, especially where docking to the ACE2 receptor is involved, there are far too many mutations (Nerd has power 2020).

This is why it is thought that Shi Zhengli wrote the BATCoV RATG13 artificially on the computer (Mosher 2020), in which she took the SarsCoV-2 virus as a template and modified it slightly. So the chronological order would have been reversed. Sars-2 caused the epidemic in Wuhan from autumn 2019. China's aim was to cover up the background of Sars-2. That is why the zoonosis theory was chosen. But to do this, there had to be a link virus from the animal kingdom. This was the artificially constructed BATCoV RATG13 virus. Why has no one been able to replicate the virus and try it on bats? 


\section{Overview and discussion}

Finally, the theories of origin of the corona virus are graphically represented once again and provided with a probability of occurrence.

Figure 1: Synopsis of the possible corona origin theories

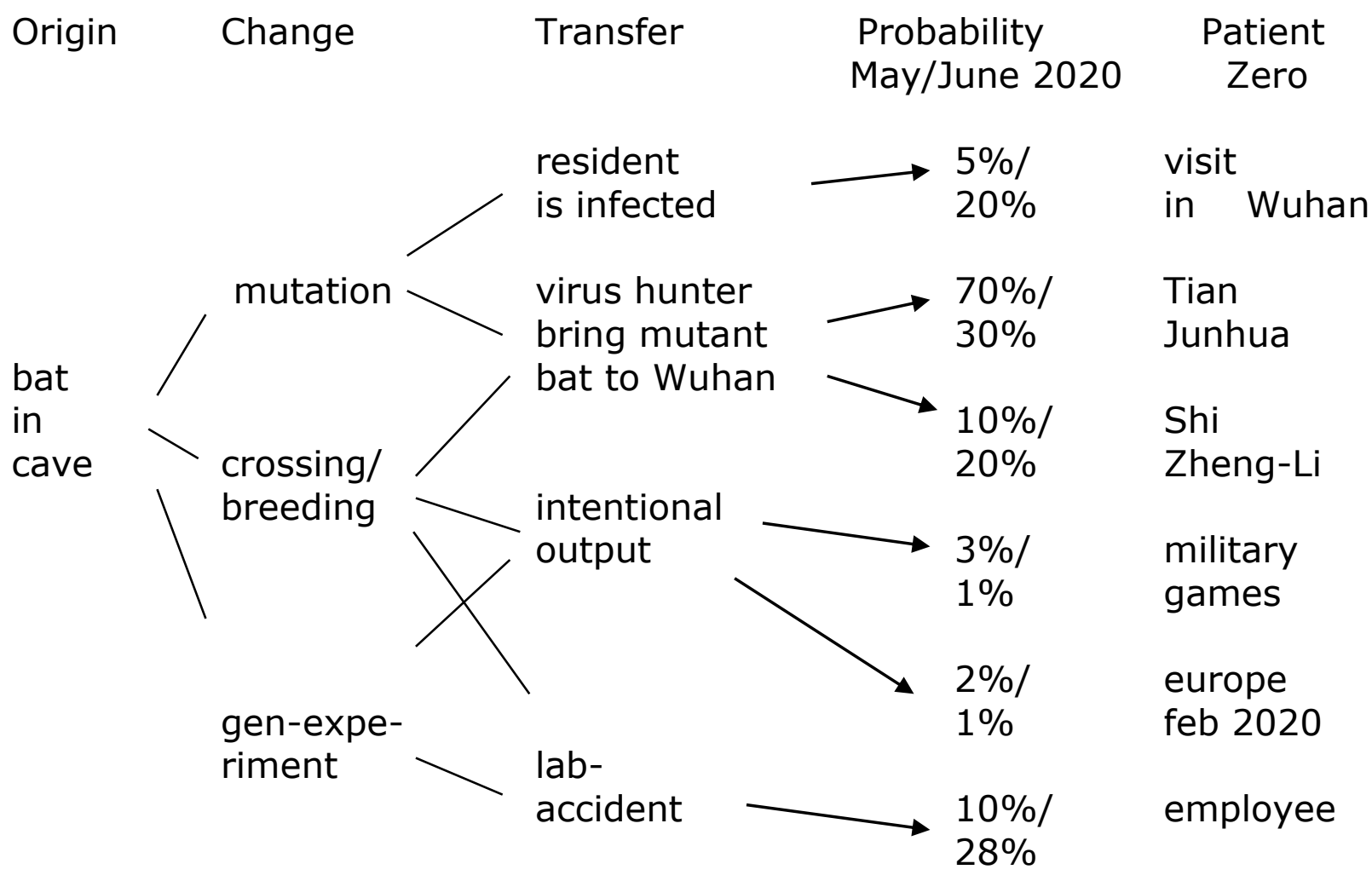

The possible paths of origin are weighed against each other in figure 1 . The stated probabilities are based on self-assessments. In order to be able to judge the dynamics of the origin theories and their constancy, the first assessment of May 2020 is supplemented by the second assessment one month later in June 2020. Certainly, each country has different assessments of the probability of the paths of origin.

The main hypothesis of the governments that the disease originated at the seafood market in Wuhan, where a mutated Sars-2 bat infected a pangolin that infected a trader/buyer, is no longer presented. There were no bats and no pangolins at the seafood market. No Sars-2 bat flies $1360 \mathrm{~km}$ through China, only to land as a shy animal on the seafood market of the metropolis of Wuhan. Even the chain of effects of the bat virus $(96.2 \%=$ Sars-2) $=>$ PangolinCoV $(91.02 \%=$ Sars- 2$)=>$ human $(100 \%=$ Sars- 2$)$ does not seem very logical (Zhang et al. 2020). The overtuning of the pangolin virus should have been between $96.2 \%$ and $100 \%$ of Sars-2. The Malaysian pangolins were confiscated in Guangzhou from illegal import to China (Liu 2020). Guangzhou is $1150 \mathrm{~km}$ away from the bat cave in Yunnan. The bats of Shitou Cave never came close to these pangolins in the wild and could not infect them. The effect chain Shitou bat $=>$ Malaysian pangolin => human cell can only have occurred in the laboratory. 
The most frequently mentioned patient zero from Hubei (Wuhan) from December 1, 2019 had no contact with the seafood market. The Chinese patient zero, Wei Guixian, who reported sick on December 10, 2019, worked at the seafood market in Wuhan, but was a shrimp and not a bat seller (Weimer 2020). The French patient zero was a fish seller (Kruger 2020). The outbreak in Beijing in June 2020 could be traced back to a salmon board (Kretschmer 2020). There is no evidence of bats.

The outbreak on the seafood market occurred in mid to late December 2019, around a month after the first infected people in Wuhan in November 2019, as some reports show: "In midNovember, the first person in Wuhan was infected with the corona virus" (Deuber 2020). Harvard researchers were able to see from satellite images from Google Earth that Wuhan's Tianyou Hospital already had much more car traffic and much fuller visitor parking spaces in September and October 2019 compared to the same months last year (T-Online 2020). This is proof that the disease epidemic in Wuhan did not break out in the second half of December 2019 , as officially stated, but earlier.

The zoonosis origin theory was first announced at an official press conference of the Chinese government on January 22, 2020 by Gao Fu, director of the Chinese Centre for Disease Control and Prevention. He claimed that the new coronavirus had been transmitted from animals to humans in the market (Echtermann 2020). This was to substantiate that the corona virus is not transmitted from humans to humans. The zoonosis theory was thus proclaimed to deny human-to-human transmission. There is nothing left of the missing human-to-human transmission. It is strange that the animal-market-to-human transmission theory is then still held on. The zoonoses theory was proclaimed by the Chinese Centre for Disease Control and Prevention (headquarters Beijing). The Wuhan Centre for Disease Control and Prevention of the same name was strongly suspected of being the cause of the coronavirus. Actually, it is quite obvious that they referred to the seafood market 280 meters away in order to divert attention from the blame of a biological laboratory. The director could not even name the animal from which the virus was transmitted to humans at the animal market. In short; the zoonosis origin theory is very unlikely. In fact, it is so unrealistic that it could be classified as a conspiracy theory.

A twist on the origin story is astonishing. Gao Fu, director of the Centre for Disease Control and Prevention (Beijing), who already sent the first experts to Wuhan on December 31, 2019 (The Thaiger 2020), gave an interview in May 2020 in which he spoke of the fact that the animal market was not the origin but a victim of the corona virus. "Gao said he had gone to Wuhan to collect samples for COVID-19 researchers in early January, but no viruses were detected in the animal samples. Viruses were only found in environmental samples, including sewage" (Global Times 2020). The animals at the fish market were therefore free of SarsCoV-2 virus and thus not the carrier of the corona virus. This results in the absurd situation in July 2020 that the Chinese themselves have withdrawn the zoonosis-animal market theory, while the WHO and the German government continue to hold on to it. 


\section{References}

Andersen, K.G., Rambaut, A., Lipkin, W.I. et al. (2020). The proximal origin of SARS-CoV2. Nature Medicine, 26, 17.03.2020, 450-452, https://doi.org/10.1038/s41591-020-0820-9.

Anonymous group of researchers (2020). Evidence SARS-CoV-2 Emerged From a Biological Laboratory in Wuhan, China, 16. April 2020 (updated 2. Mai), https://projectevidence.github.io/ (14.06.2020)

archive today (2017). Nach den 80ern fing der Typ Mücken und wog sie und ging nachts in die Berge, um Zehntausende Fledermäuse zu fangen, 05.04.2017, http://archive.vn/wlb1r\#selection-305.79-305.144 (05.07.2020).

Arré, B. (2020). The Covid-19 "Patient Zero" Conspiracy Theory that Ruined the Life of America's Maatje Benassi. Arré, 28.04.2020, https://www.arre.co.in/coronavirus/the-covid-19patient-zero-conspiracy-theory-that-ruined-the-life-of-maatje-benassi/ (06.07.2020).

Ärzteblatt (2008). SARS-Virus im Labor künstlich hergestellt. Ärzteblatt, 27.11.2008, https://www.aerzteblatt.de/treffer?mode=s\&wo=21\&s=open\&typ=1\&nid=34565 (06.07.2020).

bar/sid (2020). Waren die Militärweltspiele in Wuhan der erste Corona-"Superspreader"?

Die Sportschau, 08.05.2020, https://www.sportschau.de/weitere/wuhan-coronamiltaerfestspiele-superspreader-100.html (06.07.2020).

Becker, M.M. (2008). Synthetic recombinant bat SARS-like coronavirus is infectious in cultured cells and in mice. PNAS (Proceedings of the National Academy of Science of the United States of America), 2008, doi10.1073pnas.0808116105\%20pna (06.07.2020).

Boytchev, H. (2016). Ebola und Sars ziehen an die Ostsee. Zeit, 16.06.2016, https://www.zeit.de/wissen/gesundheit/2016-09/tierseuchen-forschung-risiko-labor-riemsebola-sars-zika (06.07.2020).

Bundesregierung (2020). Coronavirus in Deutschland, https://www.bundesregierung.de/bregde/themen/coronavirus/mythen-corona-ursprung-1750158 (July 5, 2020).

Burke, K. (2020). China's 'bat woman' Shi Zhengli warns more viruses to come. News.com, 26.05.2020, https://7news.com.au/lifestyle/health-wellbeing/chinas-bat-woman-shi-zhengliwarns-more-viruses-to-come-c-1059868 (06.07.2020).

Centers for Desease Control and Prevention (2020). Outbreak of Lung Injury Associated with E-cigarette Use, or Vaping, 25.02.2020, https://www.cdc.gov/tobacco/basic_information/ecigarettes/severe-lung-disease.html (06.07.2020).

Cui, J., Li, F., \& Shi, Z. (2019). Origin and evolution of pathogenic coronaviruses. Nature Reviews Microbiology, 17, 181-192. https://doi.org/10.1038/s41579-018-0118-9

Deuber, L. (2020). So vertuschte China das Virus. BaZ Ausland, 06.04.2020, https://www.bazonline.ch/so-vertuschte-china-das-virus-583806407705 (06.07.2020).

Dilanian, K., Arrow, R., Kube, C., Lee, C.E., Jones, L., Lorand, B. (2020). Report says cellphone data suggest October shutdown at Wuhan lab, but experts are sceptical. NBC, 
09.05.2020, https://www.nbcnews.com/politics/national-security/report-says-cellphone-datasuggests-october-shutdown-wuhan-lab-experts-n1202716 (06.07.2020).

dpa-AFX: VIRUS/Zwei Fälle in Italien: Flugverkehr von und nach China gestoppt. Onvista, 30.01.2020, https://www.onvista.de/news/virus-zwei-faelle-in-italien-flugverkehr-von-und-nachchina-gestoppt-324140407 (06.07.2020).

Dreis, A. (2020). Militärweltspiele in Wuhan. Keine besonderen Vorkommnisse. Frankfurter Allgemeine Zeitung, 14.05.2020, https://www.faz.net/aktuell/sport/mehrsport/militaerweltspiele-wuhan-keine-corona-faelle-bei-deutscher-delegation-16769106.html (06.07.2020).

Echtermann, A. (2020). Keine Belege, dass ein Markt mit exotischen Tieren in Wuhan der Ursprung des neuen Coronavirus war. Correktiv, 28.01.2020, https://correctiv.org/faktencheck/medizin-und-gesundheit/2020/01/28/keine-belege-dass-einmarkt-mit-exotischen-tieren-in-wuhan-der-ursprung-des-neuen-coronavirus-war (06.07.2020).

Einhundertzweiundachtzigtage (2020). Woher kommt das Coronavirus wirklich?, 13.04.2020, https://182tage.net/blog/archive/8309 (06.07.2020).

est (2020). Stammt das Coronavirus von Hundekot? Wiener Zeitung, 14.04.2020, https://www.wienerzeitung.at/nachrichten/wissen/mensch/2057355-Stammt-das-Coronavirusvon-Hundekot.html (06.07.2020).

Felder, G. (2020). Chinesen forschten seit Jahren an gefährlichen Viren. War das WuhanLabor nicht sicher genug?, in: Blick, 17.04.2020, https://www.blick.ch/news/ausland/chinesenforschten-seit-jahren-an-gefaehrlichen-viren-war-das-wuhan-labor-nicht-sicher-genugid15847731.html (06.07.2020).

Ge, X-Y., Li, J-L., Yang, X., Daszak, P., Shi, Z. et al. (2013). Isolation and characterization of a bat SARS-like coronavirus that uses the ACE2 receptor. Nature, 503, 535-538, https://doi.org/10.1038/nature12711.

Global Times (2020). Wuhan's Huanan seafood market a victim of COVID-19: CDC director. Global Times, 26.05.2020, https://www.globaltimes.cn/content/1189506.shtml (06.07.2020).

Heinen, N. (2020). Ischgls Glück im Unglück. Welt, 02.07.2020, 20.

Hellmeyer, F. (2020). Zwei Anomalien zeitgleich im Oktober in Wuhan. Goldseiten, 21.04.2020, https://www.goldseiten.de/artikel/447363--Zwei-Anomalien-zeitgleich-im-Oktoberin-Wuhan.html (06.07.2020).

Hu, B., Zeng, L-P., Yang, X-L., Ge, X-Y., Zhang, W., Li, B., et al. (2017). Discovery of a rich gene pool of bat SARS-related coronaviruses provides new insights into the origin of SARS coronavirus. PLoS Pathogen (Public Library of Science), 13 (11). doi.org/10.1371/journal.ppat.1006698.

Ibbetson, R. (2020). Die European athletes catch coronavirus while competing at World Military Games in Wuhan in October. Daily Mail, 06.05.2020, 
https://www.dailymail.co.uk/news/article-8291755/Did-European-athletes-catch-coronaviruscompeting-World-Military-Games-Wuhan-OCTOBER.html (06.07.2020).

jm (2020). Großbritannien sucht vergeblich „Patient null“. Welt, 18.06.2020, 22.

ka (2020). Verdacht: Sportgroßveranstaltung begünstigte Ausbreitung von SARS-CoV-2. Militärweltspiele in Wuhan als Coronavirus-Superverbreiter? Südtirol News,

08.05.2020, https://www.suedtirolnews.it/italien/militaerweltspiele-in-wuhan-als-coronavirussuperverbreiter (06.07.2020).

Köppe, J. (2020). Was Forscher über den Ursprung der Pandemie wissen. Spiegel, 28.04.2020, https://www.spiegel.de/wissenschaft/medizin/coronavirus-warum-viren-in-tierenso-gefaehrlich-sind-a-bcfe8de8-3e04-49e8-9955-6f00e382d309 (06.07.2020).

Kretschmer, F. (2020). Corona-Ausbruch in Peking: Regierung im „Kriegszustand“. Berliner Morgenpost, 17.06.2020, https://www.morgenpost.de/politik/article229327574/CoronaAusbruch-in-Peking-So-radikal-kaempft-China-gegen-das-Virus.html (06.07.2020).

Krishnasamy, V.P., Hallowell, B.D., Ko, J.Y., et al. (2020). Characteristics of a Nationwide Outbreak of E-cigarette, or Vaping, Product Use-Associated Lung Injury - United States, August 2019-January 2020. MMWR Morbidity and Mortality Weekly Report, 6990-6994, DOI: http://dx.doi.org/10.15585/mmwr.mm6903e2external icon (06.07.2020).

Krüger, P-A. (2020). Spur aus der Gefriertruhe. Beginn der Corona-Pandemie. Süddeutsche Zeitung, 08.05.2020, https://www.sueddeutsche.de/wissen/coronavirus-beginn-pandemie1.4900661 (06.07.2020).

Kupferschmidt, K. (2020). Der Stammbaum der Pandemie. Spektrum, 18.03.2020, https://www.spektrum.de/news/der-stammbaum-der-pandemie/1713516 (06.07.2020).

Liu, P. et al. (2019). Viral Metagenomics Revealed Sendai Virus and Coronavirus Infection of Malayan Pangolins (Manis javanica). Viruses, 11 (11), 24.10.2019, 979, doi.org/10.3390/v11110979 (06.07.2020).

Lu, R. et al. (2020). Genomic characterisation and epidemiology of 2019 novel coronavirus: implications for virus origins and receptor binding. Lancet, 395, 25.01.2020, 565-574. https://doi.org/10.1016/S0140-6736(20)30251-8

Lützow, S. (2020). Corona-Pandemie: Ein militärischer Anfangsverdacht. Der Standard, 09.05.2020, https://www.derstandard.de/story/2000117381867/corona-pandemie-einmilitaerischer-anfangsverdacht (06.07.2020).

Margollin, J., Meek, J. G. (2020). Intelligence report warned of coronavirus crisis as early as November: Sources. abcNews, 09.04.2020, https://abcnews.go.com/Politics/intelligencereport-warned-coronavirus-crisis-early-november-sources/story?id=70031273 (06.07.2020).

Mirke, T. (2020). Woher kommt das Coronavirus wirklich, 13.04.2020, https://182tage.net/blog/archive/8309 (06.07.2020).

monitor (2020). Im Corona - Epizentrum: Was geschah in Norditalien? Monitor, 06.06.2020, 
https://www1.wdr.de/daserste/monitor/videos/video-epizentrum-der-corona-infektionen-wasgeschah-in-norditalien-100.html (06.07.2020).

Mosher, S.W. (2020). Was the coronvirus created by Chinese scientist who tried to cover her tracks - and failed? Population Research Institute, 20,05.2020, https://www.pop.org/was-thecoronavirus-created-by-chinese-scientist-who-tried-to-cover-her-tracks-and-failed/ (06.07.2020).

Nerd has Power (2020). RATG13 - the undeniable evidence that the Wuhan coronavirus is man-made, 10.05.2020, https://nerdhaspower.weebly.com/ratg13-is-fake.html (06.07.2020).

Niedersächsisches Landesgesundheitsamt (2020): Coronavirus: Aktuelle Lage in Niedersachsen, https://www.nlga.niedersachsen.de/startseite/ (05.07.2020).

Norhoff, E. (2019). Krise in China: Schweinepest dezimiert Bestände. Welternährung, 10/2019, 26.11.2019, https://www.welthungerhilfe.de/welternaehrung/rubriken/krisenhumanitaere-hilfe/china-krise-durch-afrikanische-schweinepest/ (06.07.2020).

Prowildlife (2016). Schuppentier (Pangolin). das meistgewilderte Säugetier der Welt. https://www.prowildlife.de/wp-content/uploads/2016/09/Pangolin-CITES_2016.pdf (06.07.2020).

Qiu, J. (2020). How China's 'Bat Woman' Hunted Down Viruses from SARS to the New Coronavirus" and "Chasing Plagues". Scientific American, 322, 6, 24-32 (June 2020), doi:10.1038/scientificamerican0620-24.

Ren, W., Shi, Z. et al. (2008). Difference in Receptor Usage between Severe Acute Respiratory Syndrome (SARS) Coronavirus and SARS-Like Coronavirus of Bat Origin. Journal of Virology, Feb. 2008, 1899-1907. https://doi.org/10.1128/JVI.01085-07

rme/Ärzteblatt (2020). Archäologen: SARS-CoV-2 gelangte über Deutschland und Singapur nach Italien. Ärzteblatt, 09.04.2020, https://www.aerzteblatt.de/nachrichten/111889/Archaeologen-SARS-CoV-2-gelangte-ueberDeutschland-und-Singapur-nach-Italien\#group (06.07.2020).

Robert-Koch-Institut (2020). Erfassung der Sars-CoV-2-Testzahlen in Deutschland. $\begin{array}{lll}\text { Epidemiologisches } \quad \text { Bulletin, 22, 28.05.2020, } & \text { 22, }\end{array}$ https://www.rki.de/DE/Content/Infekt/EpidBull/Archiv/2020/Ausgaben/22_20.pdf?_blob=publi cationFile (06.07.2020).

Robert-Koch-Institut (2020). Was ist über die Ursache dieses Ausbruchs bekannt? https://www.rki.de/SharedDocs/FAQ/NCOV2019/gesamt.html;jsessionid=29046E8F082662DA D1C4216B1DDC12D1.internet072?nn=13490888 (05.07.2020).

Rüb, M. (2020). Coronavirus in Bergamo: Die Wut der Hinterbliebenen. Frankfurter Allgemeine Zeitung, 09.06.2020, https://www.faz.net/aktuell/gesellschaft/gesundheit/coronavirus/corona-in-bergamo-buergerfordern-aufklaerung-zu-hoher-toten-zahl-16807744.html (06.07.2020). 
Sauter-Orengo, L. (2020). Dort ging alles los: Webasto-Chef spricht bei „Markus Lanz“ über Coronavirus - „Es war ein Schock“. Merkur, 22.04.2020, https://www.merkur.de/lokales/starnberg/stockdorf-ort29494/coronavirus-markus-lanz-zdf-talkwebasto-chef-covid19-schock-stockdorf-bayern-zr-13581902.html (06.07.2020).

Stiftung Universitätsmedizin Essen: Coronavirus: Labor-Kooperation mit Wuhan zahlt sich aus. Healthcare in Europe, 17.03.2020, https://healthcare-ineurope.com/de/news/coronavirus-labor-kooperation-mit-wuhan-zahlt-sich-aus.html (06.07.2020).

tberg (2020). Warum Sars-CoV-2 wohl keine Biowaffe ist. Der Standard, 20.04.2020, https://www.derstandard.de/story/2000116995716/warum-sars-cov-2-wohl-keine-biowaffe-ist. (06.07.2020).

The New York Times (2019). Deadly Germ Research Is Shut Down at Army Lab Over Safety Concerns. The New York Times, 05.08.2019, https://www.nytimes.com/2019/08/05/health/germs-fort-detrick-biohazard.html (06.07.2020).

The Thaiger: Coronavirus (Covid-19). The timeline of a pandemic - the early days of Covid19. The Thaiger, 04.07.2020, https://thethaiger.com/coronavirus/the-timeline-of-a-pandemicthe-early-days-of-covid-19 (04.07.2020).

The University of Sidney (2020). Statement from Prof Edward Holmes on the SARS-CoV-2 virus. On the origins of the virus that causes COVID-19,

16 April 2020, https://www.sydney.edu.au/news-opinion/news/2020/04/16/COVID-19statement-professor-edward-holmes-sars-cov-2-virus.html https://doi.org/10.1055/s-0040-1710758

(06.07.2020).

T-Online (2020). Satellitenbilder liefern neuen Hinweis zu Corona-Ausbruch. $t$-online, 09.06.2020, https://www.t-online.de/tv/news/panorama/id_88023874/satellitenbilder-weisenauf-frueheren-corona-ausbruch-in-china-hin.html (06.07.2020).

Wang, N., Li, S-Y., Xang, X. u.a. (2018). Serological Evidence of Bat Sars-related Coronavirus Infection in Humans, in: China. Virologica Sinica 33, 2018, 104-107. https://doi.org/10.1007/s12250-018-0012-7

Washington Post (2020). State Department cables warned of safety issues at Wuhan lab studying bat coronaviruses. Washington Post, 14.04.2020,

https://www.washingtonpost.com/opinions/2020/04/14/state-department-cables-warnedsafety-issues-wuhan-lab-studying-bat-coronaviruses/ (06.07.2020).

Weimer, W. (2020). Person der Woche: Zheng-Li Shi. Hat China Angst vor der Wahrheit? NTV, 14.04.2020, https://www.n-tv.de/politik/politik_person_der_woche/Hat-China-Angst-vorder-Wahrheit-article21711861.html (06.07.2020).

WHO: Report of the WHO-China Joint Mission on Coronavirus Disease 2019 (COVID-19), 1624. Februar 2020, https://www.who.int/docs/default-source/coronaviruse/who-china-jointmission-on-covid-19-final-report.pdf (06.07.2020). 
WHO: Orgin of SARS-CoV-2, https://apps.who.int/iris/bitstream/handle/10665/332197/WHO2019-nCoV-FAQ-Virus_origin-2020.1-eng.pdf. [July 15, 2020]

Wuhan Institute of Virology (2019). Post-doctoral Recruitment Notice, https://www.zerohedge.com/s3/files/inline-

images/wuhan\%20bat\%20google\%20translated.jpg?itok=jdz-d7vU (06.07.2020).

Wurzel, S. (2020). China droht Australien mit Boykott. Tagesschau, 30.04.2020, https://www.tagesschau.de/ausland/china-australien-streit-101.html (06.07.2020).

Xiao, B. \& Xiao, L. (2020). The possible origin of 2019-nCoV coronavirus. Researchgate.net, https://img-prod.tgcom24.mediaset.it/images/2020/02/16/114720192-5eb8307f-017c-4075a697-348628da0204.pdf (06.07.2020).

Zhang, L., Shen, Fu-M., Chen, F., \& Zhenguo, L. (2020). Origin and Evolution of the 2009 Novel Coronavirus. Clinical Infectious Diseases, 03.20.2020, doi.org/10.1093/cid/ciaa112 (06.07.2020).

Zhang, T., Wu, Q., \& Zhang, Z. (2020). Probable Pangolin origin of Sars-CoV-2 associated with the Covid-19 outbreak. , 30, 1346-1351, 06.04.2020, DOI: 10.1016/j.cub.2020.03.022.

Zhen, S. (2020). Die Gerüchte über das Auslaufen von Viren im Wuhan Research Institute sind noch im Gange. rfi, 17.02.2020, rfi.fr/cn/... (Mandarin-Schrift) (03.06.2020)

Zhou, P., Yang, X-L. [...] Shi, Z.-L. (2020). A pneumonia outbreak associated with a new coronavirus of probable bat origin. Nature, 579, 270-273. https://doi.org/10.1038/s41586-0202012-7 